\title{
Faktor yang Mempengaruhi Bidan dalam Inisiasi Laktasi di Klinik Bersalin Kota Banda Aceh Nanggroe Aceh Darussalam
}

\author{
Husnah $^{1}$, Detty Siti Nurdiati ${ }^{2}$, Emy Huriyati ${ }^{3}$ \\ ${ }^{1}$ Fakultas Kedokteran Universitas Syah Kuala Nangroe Aceh Darussalam \\ ${ }^{2,3}$ Fakultas Kedokteran Universitas Gajah Mada Yogyakarta
}

\begin{abstract}
Abstrak
Pemberian ASI direkomendasikan sesegera mungkin atau 30 menit sampai satu jam setelah bayi lahir. Inisiasi dini akan mempengaruhi produksi ASI dan mencegah angka kesakitan serta kematian bayi yang disebabkan infeksi. Meskipun demikian beberapa penelitian menunjukkan bahwa prevalensi inisiasi dini masih relatif rendah tergentung faktor ibu dan bidan penolong persalinan. Penelitian kuantitatif observational dengan pendekatan cross sectional bertujuan untuk mengidentifikasi pengetahuan, sikap, perilaku dan lama bekerja bidan yang melakukan inisiasi dini di klinik Bersalin Banda Aceh. Data kualitatif diambil melalui wawancara mendalam. Sampel diambil dengan cara purposive sampling dari populasi semua bidan yang bekerja di Klinik bersalin Banda Aceh. Data dianalisis dengan univariat, bivariat chi square dan multivariat regresi logistik. Hasil analisis bivariate ada pengaruh antara pengetahuan dan perilaku terhadap inisiasi laktasi adalah $p<0.05$, akan tetapi variabel sikap dan lama bekerja bidan yang melakukan inisiasi laktasi tidak berpengaruh terhadap inisiasi laktasi. Analisis multivariat menunjukan bahwa pengetahuan dan perilaku memiliki hubungan dengan inisiasi laktasi $(p=0,041 \mathrm{OR}=3,94(95 \%-\mathrm{Cl}: 1.05-14.69)$ and $(p=0,016 \mathrm{OR}=4,52(95 \%-\mathrm{Cl}: 1.32-15.46)$. dapat disimpulkan bahwa variabel pengetahuan dan perilaku bidan memiliki hubungan dengan inisiasi laktasi, sedangkan sikap dan lama bekerja dari bidan tidak ada hubungan dengan inisiasi laktasi.
\end{abstract}

Kata kunci: pengetahuan, sikap, perilaku, lama bekerja, bidan, inisiasi laktasi

\section{Factors Influencing Midwives in Lactation initiation at Maternity Clinic of Banda Aceh Municipality, Nanggroe Aceh Darussalam}

\begin{abstract}
Breastfeeding is recommended soon or 30 minutes to an hour after childbirth. Breastfeeding or initiation of lactation will affect successful continuity of breast milk supply and prevent infant morbidity and mortality caused by infection. However, some studies convey that the prevalence of lactation initiation is still relatively low due to factors of mothers and midwives who assist childbirth. This was a quantitative observational study with cross sectional design aimed to identify the effect of knowledge, attitude, behavior and duration of occupation of midwives to lactation initiation at maternity clinic of Banda Aceh Municipality. Qualitative data were obtained through indepth interview. Samples were purposively chosen from all midwives working at maternity clinic of Banda Aceh Municipality. Data analysis used univariable, bivariable with Chi square and multivariable with logistic regression. The result of bivariable analysis showed that knowledge and behavior of midwives affected lactation initiation $(p<0.05)$ whereas variable of attitude and duration of midwives' occupation did not affect lactation initiation. The result of multivariable analysis showed that knowledge and behavior of midwives affected lactation initiation $(p=0,041 \mathrm{OR}=3,94(95 \%-\mathrm{Cl}: 1.05-14.69)$ and $(p=0,016 \mathrm{OR}=4,52(95 \%-\mathrm{Cl}$ : 1.32 - 15.46). In conclusion, variables of knowledge and behavior of midwives affected lactation initiation whereas variable of attitude and duration of midwives' occupation did not affect lactation initiation.
\end{abstract}

Keywords: Knowledge, attitude, behavior, duration of occupation, midwives, lactation initiation

Info Artikel:

Artikel dikirim pada 29 Januari 2013

Artikel diterima pada 07 Februari 2013 


\section{Pendahuluan}

Air Susu Ibu (ASI) adalah makanan terbaik yang dapat diberikan oleh seorang ibu kepada anak yang baru dilahirkan. Selain komposisinya sesuai untuk pertumbuhan dan perkembangan bayi yang berubah sesuai dengan kebutuhan bayi pada setiap saat, ASI mengandung zat pelindung yang dapat menghindari dari berbagai penyakit infeksi. Pemberian ASI juga mempunyai pengaruh emosional yang mempengaruhi hubungan batin ibu dan anak serta perkembangan jiwa si anak ${ }^{1}$.

Bayi yang mendapat ASI akan lebih terjaga dari penyakit infeksi terutama diare dan Infeksi Saluran Pernapasan Atas (ISPA) dibandingkan dengan bayi yang mendapat susu formula, dimana ASI memegang peranan penting untuk menjaga kesehatan dan kelangsungan hidup bayi. Awal menyusui yang baik adalah 30 menit setelah lahir karena dapat merangsang pengeluaran ASI selanjutnya, disamping itu akan terjadi interaksi dengan cepat antara ibu dengan bayi. ${ }^{2,3}$ Pemberian ASI yang dianjurkan adalah pemberian ASI segera (30 menit-1 jam) setelah melahirkan, dilanjutkan pemberian ASI saja atau ASI Ekslusif hingga usia 6 bulan dan pemberian Makanan Pendamping ASI (MPASI) setelah umur 6 bulan serta tetap memberikan ASI sampai umur 2 tahun atau lebih. ${ }^{4}$

Bayi yang diberi susu selain ASI, mempunyai risiko 17 kali lebih besar mengalami diare dan 3-4 kali lebih besar terkena ISPA dibanding dengan bayi yang mendapat ASI. ${ }^{5}$ Pemberian kolostrum mempunyai implikasi terhadap kesehatan bayi karena mengandung zat imonologik dan anti infeksi terhadap bakteri, virus dan jamur. Bila inisiasi laktasi terlambat diberikan maka pemberian suplemen makanan prelakteal berupa cairan pada bayi sejak dini tidak dapat dihindarkan, kemungkinan bayi terkena diare akan semakin besar. ${ }^{2,4,5}$

Masih banyaknya ibu yang menunda inisiasi laktasi menyebabkan bayi mendapat makanan prelakteal dan kemampuan dari bayi untuk mengisap ASI berkurang, ibu yang memberi ASI dalam 1 jam pertama setelah melahirkan mempunyai peluang 2-8 kali lebih besar untuk memberikan ASI selanjutnya. Ibu yang segera kontak dan menyusui bayinya ternyata $77 \%$ berhasil menyusui bayinya dibandingkan yang tidak segera kontak hanya $27 \%$ berhasil menyusui bayinya. ${ }^{5,6}$

Penolong persalinan berhubungan dengan pemberian ASI 1 jam pertama, Penolong persalinan merupakan kunci utama keberhasilan inisiasi ASI dalam 1 jam pertama setelah melahirkan karena dalam waktu tersebut peran penolong persalinan masih sangat dominan. ${ }^{6,7}$ Pengetahuan petugas kesehatan tentang manajemen laktasi memberikan kontribusi besar dalam keberhasilan menyusui dini. ${ }^{8}$
Berdasarkan Survey Demografi Kesehatan Indonesia (SDKI) 2003 pemberian ASI pada hari pertama hanya $3,7 \%$. Padahal inisiasi laktasi telah menjadi program Nasional dan Internasional sejak dicanangkannya Rumah Sakit Sayang Bayi pada tahun 1991, namun dalam pelaksanaannya menunjukkan prevalensi inisiasi laktasi masih sangat rendah. ${ }^{1,2}$ Sebagian besar ibu (76\%) menyatakan bahwa sumber promosi susu formula adalah pelayanan kesehatan. Ibu melihat iklan susu formula di rumah sakit (21\%), di klinik swasta (19,5\%) dan di puskesmas $(19,5 \%)$. Ibu-ibu menerima susu formula bayi melalui rumah sakit atau rumah bersalin (60\%), ibu menerima hadiah dari perusahaan susu formula untuk bayi $(40 \%)$. Dan $14,8 \%$ bidan menyatakan setuju untuk memberi susu formula kepada bayi baru lahir. ${ }^{1,2}$

Inisiasi laktasi sangat perlu dilaksanakan dengan baik dan benar, baik oleh ibu maupun petugas kesehatan dimana peran petugas dalam membantu ibu selama proses persalinan dan perawatan di dalam ruang bersalin sangat dominan khususnya untuk inisiasi laktasi. 2, 3, 6 Bayi yang tidak memulai inisiasi menyusui sampai lewat 24 jam menunjukkan 2,5 kali risiko dapat meninggal dibandingkan bayi yang inisiasi menyusui dalam 1 jam pertama. ${ }^{9}$

Penelitian ini bertujuan untuk mengetahui pengaruh pengetahuan, sikap, perilaku dan lama kerja bidan terhadap inisiasi laktasi di klinik bersalin Kota Banda Aceh.

\section{Bahan dan Metode}

1. Rancangan dari Subjek Penelitian

Jenis penelitian ini adalah penelitian observasional dengan rancangan cross sectional. Populasi penelitian adalah seluruh bidan di kota Banda Aceh dan penentuan sampel secara purposive yaitu: seluruh bidan yang bekerja di 6 klinik bersalin kota Banda Aceh berjumlah 55 orang dan memenuhi kriteria inklusi : Bidan yang bertempat tinggal di kota Banda Aceh, Bidan yang bekerja menolong ibu/merawat ibu bersalin, bersedia menjadi subjek penelitian.

\section{Lokasi dan Waktu Penelitian di 6 Klinik Bersalin}

Penelitian dilakukan di Kota Banda Aceh dengan waktu penelitian selama 3 bulan yaitu mulai bulan September-November 2007.

Bulan September semua ibu yang bersalin di 6 klinik bersalin Kota Banda Aceh diwawancarai oleh surveyor dan peneliti tentang pengaruh perilaku bidan terhadap inisiasi laktasi dan bulan Oktober dilakukan wawancara kepada bidan tentang pengaruh 
pengetahuan, sikap, perilaku dan lama kerja terhadap inisiasi laktasi. Beberapa ibu bersalin dan bidan diambil secara acak di masing-masing klinik untuk indepth interview serta dilakukan observasi guna mendukung data kuantitatif.

\section{Variabel Penelitian}

Variabel penelitian meliputi variabel bebas pengetahuan, sikap, perilaku dan lama kerja bidan, sedangkan variabel terikat adalah inisiasi laktasi

\section{Jenis Data dan Cara Pengumpulan Data}

Jenis data adalah data primer yang meliputi data ibu bersalin dan bidan. Pengumpulan data dilakukan oleh peneliti yang dibantu oleh 14 orang surveyor yaitu lulusan D3 Keperawatan dan Kebidanan dengan menggunakan wawancara terstruktur, kuesioner dan indepht interview serta observasi langsung dilakukan secara acak kepada beberapa orang bidan dan ibu bersalin. Alat ukur yang digunakan pada pelaksanaan penelitian sebelumnya telah diuji validitas dan reabilitasnya.

Pengolahan dan analisis data dilakukan dengan menggunakan program SPSS. Analisis data yang dilakukan adalah analisis univariat, bivariat dan multivariat, melihat hubungan antara variabel bebas dan variabel terikat digunakan uji chi square dan analisis regresi logistik untuk mengetahui variabel yang paling berpengaruh terhadap inisiasi laktasi.

\section{Hasil dan Pembahasan}

\section{Karakteristik Responden}

Responden yang terlibat dalam penelitian ini berjumlah 55 orang bidan. Karakteristik responden sebagian besar berumur $<30$ tahun sebanyak 42 $(76,4 \%)$ dengan tingkat pendidikan sebagian besar D1-D3 sejumlah $43(78,2 \%)$. Tenaga yang bekerja di klinik Seulanga sebanyak $15(27,3 \%)$, Tingkat pengetahuan tinggi tentang inisiasi laktasi sebanyak $36(65,5 \%)$. Sikap responden tentang inisiasi laktasi sebagian besar bersikap negatif sejumlah 31 (56,4\%), sebagian besar responden berperilaku salah sejumlah $28(51 \%)$. Responden sebagian besar bekerja dengan lama kerja $<5$ tahun sejumlah $37(67,3 \%)$. Dan yang membantu/membimbing ibu bersalin untuk inisiasi laktasi sebanyak 29 (52,7\%)

Karakteristik responden yang dianalisis meliputi pengetahuan, sikap, perilaku dan lama kerja bidan terhadap inisiasi laktasi. Disajikan pada tabel 1.

Dari hasil penelitian terlihat bahwa pengaruh antara pengetahuan bidan terhadap inisiasi laktasi mempunyai nilai $p=0,004$ ada pengaruh antara pengetahuan bidan terhadap inisiasi laktasi ditunjukkan dengan nilai $\mathrm{p}<0,05$ dengan OR: 5,60 (95\%-Cl: 1.63-19.23) artinya bidan dengan pengetahuan rendah mempunyai peluang 5,60 kali untuk tidak melakukan inisiasi laktasi dibanding dengan bidan yang berpengetahuan rendah. Nasehat yang diberikan oleh bidan akan diikuti oleh ibu untuk menyusui bayinya dan ini berdampak positif bila petugas kesehatan berpengetahuan cukup tentang manajemen laktasi dan ini sangat tergantung pada pengetahuan yang diterima selama pendidikan ditambah pengetahuan selama bekerja. ${ }^{11}$ Pengetahuan petugas kesehatan memberikan kontribusi besar dalam keberhasilan menyusui. ${ }^{7,8}$ Data kualitatif bidan yang mendukung adalah :

Nanti kadang setelah bersih-bersih ibu hecting yang satu lagi segera kasih ASI,

Tabel 1. Pengaruh Karakteristik Bidan terhadap Inisiasi Laktasi di Klinik Bersalin Kota Banda Aceh

\begin{tabular}{|c|c|c|c|c|c|c|c|c|c|}
\hline \multirow[t]{3}{*}{ Variabel } & \multicolumn{4}{|c|}{ Inisiasi Laktasi } & \multirow{2}{*}{\multicolumn{2}{|c|}{ Total }} & \multirow{3}{*}{ p.Value } & \multirow{3}{*}{ OR } & \multirow{3}{*}{$(95 \%-\mathrm{Cl})$} \\
\hline & \multicolumn{2}{|c|}{ Tidak } & \multicolumn{2}{|c|}{ Ya } & & & & & \\
\hline & $n$ & $\%$ & $\mathbf{N}$ & $\%$ & $\mathbf{N}$ & $\%$ & & & \\
\hline \multicolumn{10}{|l|}{ Pengetahuan } \\
\hline a. Tinggi & 12 & 33,3 & 24 & 66,7 & 36 & 100 & 0.004 & 1 & \\
\hline b. Rendah & 14 & 73,7 & 5 & 26,3 & 19 & 100 & & 5.60 & $(1.63-19.23)$ \\
\hline \multicolumn{10}{|l|}{ Sikap } \\
\hline a. Positif & 8 & 33,3 & 16 & 66,7 & 24 & 100 & 0.068 & 1 & \\
\hline b. Negatif & 18 & 58,1 & 13 & 41,9 & 31 & 100 & & 2.76 & $(0.91-8.39)$ \\
\hline \multicolumn{10}{|l|}{ Perilaku } \\
\hline a. Benar & 7 & 25,9 & 20 & 74,1 & 27 & 100 & 0.002 & 1 & \\
\hline b. Salah & 19 & 67,9 & 9 & 32,1 & 28 & 100 & & 6.03 & $(1.87-19.44)$ \\
\hline \multicolumn{10}{|l|}{ Lama Kerja } \\
\hline a. $\geq 5$ tahun & 6 & 33,3 & 12 & 66,7 & 18 & 100 & 0.149 & 1 & \\
\hline b. $<5$ tahun & 20 & 54,1 & 17 & 45,9 & 37 & 100 & & 2.35 & $(0.72-7.61)$ \\
\hline
\end{tabular}

Sumber: Data Primer 
segera setelah lahir menurut saya 30 menit setelah lahir. (Bidan NR, 23 Thn, D3, < 5 Thn)

ASI Ekslusif ya, kontak secepat mungkin setelah lahir diletakkan di payudara ibu dibungkus langsung diletakkan di payudara ibu. Pemberian ASI secepat mungkin. (Bidan MRY, 22 Thn, D3, < 5 Thn)

Pengaruh antara sikap bidan terhadap inisiasi laktasi mempunyai nilai $p=0,068$, tidak ada pengaruh antara sikap bidan terhadap inisiasi laktasi. Ditunjukkan dengan nilai $p>0,05$ dengan OR: 2,76 (95\%-Cl; 0.91-8.39). Hasil penelitian sebelumnya dimana pelatihan terhadap inisiatif pemberian ASI terjadi perubahan efek positif pemberian ASI di kamar bersalin. ${ }^{12}$ Dan wanita yang mendapat promosi aktif terjadi peningkatan pemberian $\mathrm{ASI} .{ }^{13}$ Sikap petugas kesehatan sangat mempengaruhi pemilihan makanan bayi oleh ibu, pengaruh bisa bersikap negatif secara pasif dengan cara tidak membantu bila ada kesulitan laktasi tapi menyuruh ibu untuk segera beralih ke susu botol. ${ }^{1,2,11}$ Bidan menyatakan sikap setuju untuk memberi susu formula kepada bayi baru lahir dan ibu-ibu menerima susu formula dari rumah sakit atau rumah bersalin. ${ }^{2}$ Mempromosikan pemberian ASI kepada ibu-ibu mempunyai potensi untuk menyelamatkan kematian sesudah kelahiran. ${ }^{14}$ Data kualitatif bidan yang mendukung adalah :

Ada kami coba tapi kalau ASI belum keluar yah...kami beri susu formula biar bayi tidak dehidrasi, haus atau nangis. (Bidan HL, 38 Thn, S1, > 10 Thn)

Karena dapat bonus dari dealer susu seperti ikut seminar gratis dimana-mana, jalan-jalan, fee jadi mau aja bidan-bidan pakai sampel susu habis bonusnya menggiurkan sih bu. (Bidan WM, 37 Thn, D3, > 10 Thn)

Perilaku bidan terhadap inisiasi laktasi mempunyai nilai $p=0.002$. Ada pengaruh antara perilaku bidan terhadap inisiasi laktasi. Ditunjukkan dengan nilai $p<0,05$ dengan OR: 6.03 (95\%-Cl: 1.87-19.44) artinya bidan yang berperilaku salah mempunyai peluang 6.03 kali untuk tidak melakukan inisiasi laktasi dibandingkan dengan bidan yang berperilaku benar. Kunci utama keberhasilan pemberian ASI segera terletak pada penolong persalinan karena dalam waktu 30 menit pertama setelah bayi lahir peran penolong persalinan masih sangat dominan. ${ }^{6}$ lbu akan memulai dan meneruskan pemberian ASI jika dokter atau bidan mendukung dan memotivasi mereka. ${ }^{10}$ Data kualitatif bidan yang mendukung adalah :

\begin{abstract}
Karena setelah melahirkan ibu capek jadi peran bidan dan keluarga serta kemauan ibu. menurut saya 30 menit setelah lahir bayi langsung disusui, walaupun nanti ada pasien yang bilang ASI nya tidak keluar, nanti kita jelaskan sama pasien makin sering diisap merangsang kita jelaskan. (Bidan NR, 23 Thn, D3, <5 Thn)
\end{abstract}

Di sini segera disusui setelah bayi lahir bidan memegang mamaknya bagaimana disusui, apalagi anak pertama. Bidan berperan untuk mengajari ibunya dan ibunya juga berperan apalagi susu ekslusif. (Bidan NBT, 23 Thn, D3, <5 Thn)

Pengaruh antara lama kerja bidan terhadap inisiasi laktasi mempunyai nilai $p=0,149$ artinya tidak ada pengaruh antara lama kerja bidan terhadap inisiasi laktasi dengan nilai $p>0,05$ OR: 2,35 (95\%$\mathrm{Cl}$ : 0.72-7.61). Hasil penelitian ini tidak sesuai dengan penelitian sebelumnya dimana disebutkan bahwa semakin lama seseorang bekerja semakin berpengalaman sehingga kecakapan kerjanya semakin baik dan pengetahuan seseorang akan bertambah selama bekerja. ${ }^{15}$ Ada hubungan antara masa kerja efektif dengan tingkat pencapaian kerja bidan. ${ }^{11}$

Variabel independen yang mempunyai nilai $p$ valuenya kurang dari 0,05 yaitu variabel pengetahuan dan perilaku dilakukan analisis regresi logistik seperti terlihat pada tabel 2 .

Tabel 2

Analisis Regresi Logistik Variabel Bebas (Pengetahuan dan Perilaku) dengan Variabel Terikat (Inisiasi Laktasi)

\begin{tabular}{lccc}
\hline \multicolumn{1}{c}{ Variabel } & p. Value & OR & $(95 \%-\mathrm{Cl})$ \\
\hline $\begin{array}{l}\text { Pengetahuan } \\
\begin{array}{l}\text { a. Tinggi } \\
\text { b. Rendah }\end{array}\end{array}$ & & & \\
\hline Perilaku & 0.041 & 3.94 & $(1.05-14.69)$ \\
\hline
\end{tabular}

\begin{tabular}{|c|c|c|c|}
\hline \multicolumn{4}{|l|}{ Perilaku } \\
\hline a. Benar & & & \\
\hline b. Salah & 0.016 & 4.52 & $(1.32-15.46)$ \\
\hline
\end{tabular}

Sumber: Data Primer

Tabel analisis di atas menunjukkan bahwa dari keseluruhan analisis yang telah dilakukan dapat disimpulkan dari 4 variabel independen yang berpengaruh terhadap inisiasi laktasi adalah pengetahuan bidan $p=$ 0,041 dan perilaku bidan $p=0,016$. 
Diperkuat dengan penelitian terdahulu ibu akan memulai dan meneruskan peberian ASI jika dokter atau bidan mendukung atau memotivasi mereka. ${ }^{10}$ Dan faktor yang paling dominan berpengaruh terhadap pemberian ASI 1 jam pertama adalah tenaga periksa hamil dan penolong persalinan. ${ }^{6}{ }^{7} \mathrm{lbu}$ yang diberi konseling dan motivasi pre natal dan peri natal terjadi peningkatan pemberian $\mathrm{ASI} .{ }^{16}$ Kunci keberhasilan pemberian ASI segera terletak pada penolong persalinan. ${ }^{5,6}$ Periode pre natal, persalinan dan peri natal merupakan saat yang sangat penting untuk keberhasilan memulai dan mempertahankan menyusui karena saat itu terjadi interaksi yang sangat dekat antara bidan dengan para ibu yang memberi pengaruh besar kepada ibu terhadap proses menyusui. ${ }^{1}$ Keunggulan atau manfaat ASI harus ditunjang oleh cara pemberian yang benar, bidan sangat berperan untuk memberi dukungan kepada ibu dalam menghadapi persalinan dan keyakinan dalam keberhasilan inisiasi laktasi. $^{2}$

\section{Simpulan dan Saran}

Pengetahuan dan perilaku bidan berpengaruh terhadap Inisiasi Laktasi. Sedangkan sikap dan lama kerja bidan tidak berpengaruh terhadap Inisiasi Laktasi.

Pengetahuan bidan tentang manajemen laktasi harus lebih ditingkatkan secara berkesinambungan sehingga dapat mensosialisasikan pemberian inisiasi laktasi kepada ibu bersalin dan bidan harus berperilaku benar dalam melakukan inisiasi laktasi kepada setiap ibu bersalin.

Pelayanan kesehatan terutama klinik bersalin harus punya suatu kebijakan, khususnya oleh Ikatan Bidan Indonesia (IBI) tentang petunjuk pelaksanaan inisiasi laktasi kepada ibu bersalin.

\section{Daftar Pustaka}

1. Perinasia, (2004) Persiapan dan Teknis Menyusui, Langkah-Langkah Menuju Keberhasilan, dalam Manajemen Laktasi, Jakarta.

2. Depkes RI, (2002) Manajemen Laktasi, Buku Panduan bagi Bidan dan Petugas Kesehatan di Puskesmas, Jakarta.

3. Depkes RI, (2004), " Memulai Pemberian ASI " dalam asuhan persalinan normal, Jakarta : 4-74-10.

4. UNICEF, WHO/IDAI, (2005) Kebijakan Pemberian Makan pada Bayi, dalam Pemberian Makanan Bayi, Jakarta.

5. Irawati A, P. Junadi, (1996) Pola Inisiasi ASI dan Faktor-Faktor yang Berhubungan dengan Keterlambatan Inisiasi ASI di Indonesia, Gizi Indon, 121: 80-93
6. Fikawati, S. Syafiq, A. (2003) Hubungan antara Menyusui Segera (Immediate Breast Feeding) dan Pemberian ASI Ekslusif sampai dengan empat bulan, Jurnal Kedokteran Trisakti Vol. 22 No. 2: 47-55

7. Rahardjo, S. (2006) Faktor-faktor yang Berhubungan dengan Pemberian ASI satu jam pertama setelah melahirkan, Jurnal Kesehatan Masyarakat Nasional, Vol I No. 1: 11-17

8. Rahaju, S. (2002) Determinan keberhasilan Praktek Menyusui Dini di Rumah Sakit Umum Daerah Dr Moewardi di Surakarta, Tesis Pascasarajana Program Studi Ilmu Kesehatan Masyarakat KIA-Kesehatan Reproduksi UGM, Yogyakarta

9. Edmond, M K. Zandoh C, Quiqley AM, Etego A. S, Aqyei O. S, Kirkwood R. B, (2006) Delayed Breast Feeding Initiation Increases Risk of Neonatal Mortality, Journal of The American Academy of Pediatrics; 117; e 380-e 386.

10. Brodribb, W, Jackson C. Fallon B, A Hegney, D (2007), "Breast Feeding and The Responsibilities of GPs, "Australian Family Physician Vol 36 No 3: 283-285.

11. Hamzah, E, Suroto, (1997) Program Laktasi dan Kesiapan Petugas Kesehatan adalah Kunci Keberhasilan Laktasi dalam Soetjiningsih ASI petunjuk untuk tenaga kesehatan, EGC, Jakarta.

12. Coutinho, B.S Lima C, M. Ashworth, A. Lira C, P. (2005) The Impact of Training Based on The Baby Friendly Hospital Initiative on Breast Feeding Practices in The North East of Brazil, Journal The Pediatria, 81: 471-477.

13. Luther, K, C. Escamilla P, R. Sedall A, Sanghvi, T. Teruya, K. Wickham, C. (1997) The Effectiveness of Hospital Based Program to Promote Exclusive Breast Feeding Among Low-income Women in Brazil, American Journal of Public Health: 87: 659-663.

14. Chen A. Rogen Wj, (2004), "Breast Feeding and The Risk of Post-Noenatal Death in The United States," Pediatrics 113:435-439.

15. Elytha, F. (1994) "Hubungan faktor individu, Motivasi, Sosial Budaya dan Penunjang Kegiatan dengan Penampilan Kerja Bidan di Desa Jawa Barat, Jawa Tengah dan Sumatera Utara tahun 2003". Tesis S2 Program Pasca Sarjana, Fakultas Kesehatan Masyarakat Universitas Indonesia, Jakarta.

16. Aidam A, B. Escamilla, P. R. Lartey, A (2005) Lactation Counseling Increases Exclusive Breast Feeeding Rates in Ghana, The Journal of Nutrition: 1691-1695. 